\title{
Optimizing Storytelling through Dual Coding Theory
}

\author{
Dian Kusumawati, Yeni Rachmawati \\ Universitas Pendidikan Indonesia, Bandung, Indonesia \\ Corresponding e-mail: dianku@student.upi.edu
}

\begin{abstract}
This paper explores about how a storytelling, which has been convinced by many, as a practical learning approach to develop early childhood literacy ability, however together with the decreasing of storytelling culture in the society, it has now been lesser in use let alone to be considered as an effective learning method to practice in the kindergaren education upbringing. Nevertheless, storytelling is undoubtedly believed to improve children's literacy skills as it gives more rooms to identify new vocabulary, building imagination and exercising creative thinking. Simultaneously with research development on early childhood, there are some interesting results showing how significantly Dual Coding Theory has improved the ability on children reading comprehension. Dual Coding Theory is one of the cognitive theory developed by Allan Paivio, Professor of Psychology at the University of Western Ontario. This theory states that human being processes and stores information in two different subsystems, namely verbal and non-verbal (visual) which are correlated and work together. By exposing the entire sensory at early age, it will build an important foundation for a better understanding on the vocabulary and story ideas. It is with hope that through this article, the valuing of storytelling method by way of Dual Coding Theory can be elaborated and to position the importance of Dual Coding Theory in the development of children's literacy. It is also expected to have vivid implication on the improvement of teacher's motivation to reinforce the storytelling method in the kindergarten education as effort to set up a good literacy foundation.
\end{abstract}

Keywords: $\quad$ storytelling, early childhood, literacy, dual coding theory

\section{INTRODUCTION}

Reading opens the door to unlimited knowledge. Literacy opens the doors to knowledge and places. Therefore, reading skill is crucial and a must to master by everyone. Storytelling is essential to human life, as it is through storytelling that we get information, build awareness and understanding as well as getting knowledge. To children at early stage, storytelling is a bridge to get information, to learn about vocabulary and learn to understand ideas in a story before they have the ability to read and write

Unfortunately in these one or two decades in Indonesia, despite the understanding that early stage children in the kindergarten should not yet to formally teach how to read, nonetheless, many has began long before they entered next formal schools level as demands from primary school forcing them to start learning to read earlier.
This has intensified by the assumptions in the society that children at kindergarten who will enter primary school level should already be able to read even though the government has issued guidelines that no reading to give to children entering Elementary School level and that there are no reading lesson to conduct in kindergarten education stage (Surat Edaran Direktorat Jenderal Manajemen Pendidikan Dasar Dan Menengah Nomor 1839/C.C2/TU/2009). However, it still holds a long debate between kindergarten and first grade teacher as to when the task of teaching reading starts.

This condition has led into a less favourable learning climate where learning in the kindergarten is supposed to be fun and by means of playing to become semi-formal and rigid. Creative learning method has become lesser implemented due to the demand for teacher to teach reading, this includes the use of story-telling which considered as an effective learning method has become rarely implemented in the kindergarten educational upbringing. 
In contrast with the early stage reading implementation, fact finds that children's reading ability in Indonesia is positioned at the bottom rank based on test results done by the Organization for Economic Cooperation and Development (OECD) (Faizah, et al , 2015) .

Reading skills is obtained not only through the ability to compose letters and pronounce them but it requires the ability to understand ideas. This ability to understand is the very first thing that needed to be taught to children before they learn how to read letters as letters for them are abstract and difficult to understand.

When students entered formal education level (elementary school), they will deal a lot with long textbook readings, which is so much different from the previous books learned in the kindergarten where books are in the form of story books with more images and short texts narration. (Sentari, 2002).

This condition will require a specific learning method to enable students acquiring comprehensive reading skills, and storytelling is considered effective in helping students to understand ideas in a story.

Many researches and studies have conducted to find effective teaching models and methods to read for children (Sukartiningsih, 2005), but not many researches has specifically analyzed on how information is processed and stored by the brain as basic element for human being to build knowledge .

This article is a literature studies aims to map out some researches done on storytelling and the role of Dual Coding Theory in improving the children's literacy skills as a mean or bridge to prepare the early childhood learning reading process which will become the foundation to a better reading ability in the future. In addition to that, this article is also expected to be of useful to teachers of kindergartens and any succeeding researchers.

\section{REVIEW OF THE RELATED LITERATURE}

\section{$2.1 \quad$ Storytelling}

For chidren at early childhood, storytelling is a bridge to get information, to learn about vocabulary, and learn to understand ideas in a story before they have the ability to read and write. Some studies suggested that in order to enrich language skills of early childhood, a meaningful experience is a tool to provide opportunities to improve and sustain their language growth. (Isbell, Sobol, Lindauer, \& Lowrance, 2004).
Storytelling is different from reading a story (storyreading), storytelling is telling a story without the help of books, pictures or other props that could break the magnetic flux between the listener and the storyteller. Story-telling encourages word recognition in reading readiness, increasing vocabulary, develop imagination, help children learn to express himself verbally, develop children's ability to listen attentively, increasing attention span and concentration as well as creativity. (Chesin, 2009)

Therefore, in order to get a story delivered with all the advantages and benefits mentioned earlier, teachers need to understand the theoretical basis of Cognitive to help deliver the story-telling in a more valuable way to assist children in learning to read (reading readiness) and the one theory that could optimize the benefits of storytelling is the Dual Coding Theory. (Fredericks, 1997).

\subsection{Dual Coding Theory (DCT)}

How mind works when it putting words together while reading has become an interesting subject to study for a long time. The language and the role of mental imagery has also long been a source of fascination in scientific research on cognitive. There are several formulas that describe how information is stored and organized in our brain. One theory that states that information is received by the brain and processed as a mental representation divided into two subsystems is Dual Coding Theory. What will be presented in this paper is only a part of the application of the cognitive theory by Dual Coding Theory.

The Dual Coding Theory in an abstractly cognition way defines two different kinds of mental codes, one is a verbal code to process and digest language in all forms of sensory and the other is a nonverbal codes to represent and process information related to objects and events. Nonverbal code is also referred to as imagery system that serves to generate, analyze and synthesize the mental images from objects and events, whether visually, auditorily, or other modalities.(Paivio, 2006)

DCT has never taken something abstract into rationale; all mental representation in the DCT are associated with sensory modality (eg, such as auditory, visual, affective, etc.). Nonverbal aspects of cognition such as mental imagery is a typical aspect of the DCT in modern cognitive theory especially in the theory of literacy. (Sadoski \& Paivio, 2013).

According to Sadoski \& Paivio (2013), the basic foundations of Dual Coding Theory on cognition are associated with reading and literacy. The whole mental representations received from 
sensory experience that we encountered is encoded in the system of representation that is concrete as verbal and nonverbal units, and is classified into two separate coding systems with different characteristics and hierarchy qualitatively, but still be able to operate independently, in parallel or interconnectedly. Mental encoding is done concretatively, even abstract information such as symbols language or schematic diagrams are also encoded as in the following example: visual modalities is encoding verbally and non-verbally. A verbal encoding is mentally represent the letter $\mathrm{C}$ in the word cup, while nonverbal visual encoding can be represented in the form of a cup of coffee set on the table complete with its saucer.

In the auditory modality, encoding an oral hearing captured from the phoneme $/ \mathrm{k} /$ or pronunciation of words like $/ \mathrm{k} \mathrm{p} /$, and the verbal encoding of nonverbal can be done in the form of a cup clattering on its saucer, or the sound of coffee pouring into the cup. Encoding oral haptic can be from the fingertips sensation when touching the Braille raised dots pattern or handwriting motoric activity; writing it, saying it and writing the word of cup in a perfect way. Encoding haptic in the form of measuring the cup's weight, flexibility, and the warmth of a cup of hot coffee.

This DCT encoding and mental mode is modular. It means that they form a separate subsystem which units are structurally different but functioning independently. For example, we can recall a visual image of a cup of coffee without the presence of the aroma of coffee, its taste, the warmth of the cup, the spelling of the c-u-p word, the pronunciations of $/ \mathrm{k} \mathrm{p} /$, or motoric activity used to write the word cup, even though all of these things are interrelated and can easily influence each other in our memory, neurologically these two subsystems of the Dual Coding Theory is indeed having a different place in the brain. (Sadoski \& Paivio, 2013).

Here's a table showing orthogonal relationship between mental coding and sensori-motor modalities in the Dual Coding Theory. The examples in the below diagram are all representation types of various sensory modalities in both subsystems. Adapted from Table 1, Paivio (1972).
Table 1. Orthogonal relationship between mental coding and sensory modalities in the Dual Coding Theory

\begin{tabular}{lll}
\hline & Mental Codes & \\
\hline $\begin{array}{l}\text { Modality } \\
\text { Sense }\end{array}$ & Verbal & Nonverbal \\
Visual & $\begin{array}{l}\text { Visual language } \\
\text { (writing) }\end{array}$ & Visual objects \\
Auditor & $\begin{array}{l}\text { Auditory language } \\
\text { (speech) }\end{array}$ & $\begin{array}{l}\text { Environtmental } \\
\text { sounds }\end{array}$ \\
Haptic & Braille, & "Feel” of objects \\
Gustatory & - & Tandwriting memories \\
Olfaktory & - & Smell memories \\
Emotion & - & Feel emotions \\
\hline
\end{tabular}

According to Sadoski (2013), there are various specific evidences of modalities in the system of representation, which can be seen in the phenomenon of specific-modality interference. At the time we tried to do two different tasks in one modality, it caused disturbance in completing one task or it even interfered the completion of both tasks. For example it is difficult for us to listen to two conversations at once, both involved the same modality which is auditory. However, to do two tasks using separate modality will be easier, for example, exercising (motoric modality) while listening to music (auditory modality) without influencing each other.

In constructing a system of cognition, the cognitive theories is usually formulated by specifying the basic units or "building blocks". In the Dual Coding Theory, these units form is concrete. The term used to distinguish the two representations of the underlying neurological representations of two subsystems are logogen and imagen. Logogen is for verbal representation, encoding of verbal, mental language and inner speech; whilst imagen is for nonverbal representation, coding nonverbal, mental images or imagery.

The organizing and interconnecting in the system of verbal and imagery described as follows: 


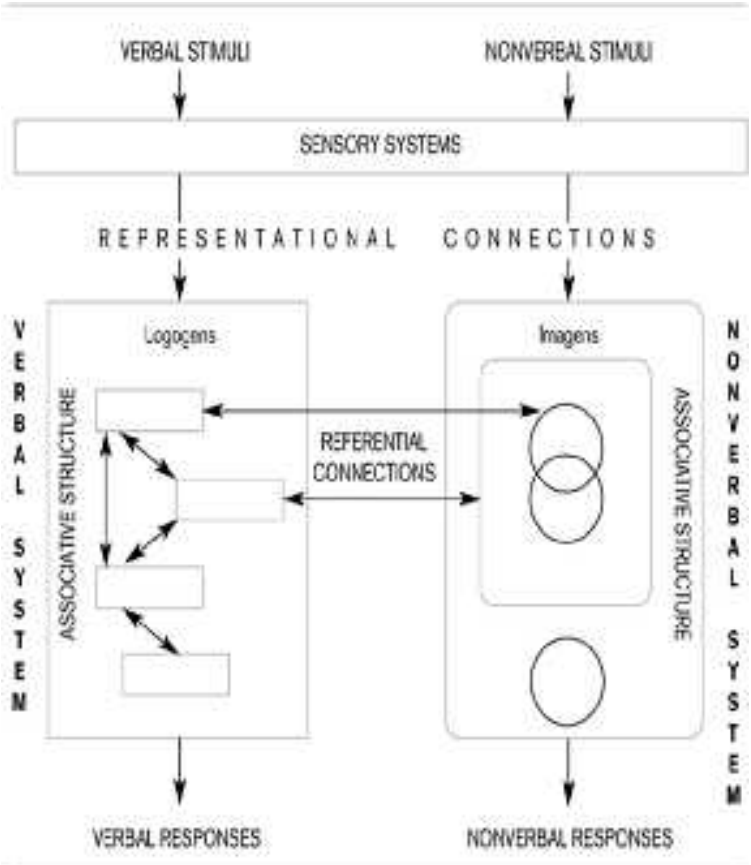

Figure 1. The organizing and interconnecting in the system of verbal and imagery

General model of DCT showing the verbal and nonverbal systems including representational units and their referential and associative interconnections, as well as connections to sensory input and response output systems. From Mental Representations: A Dual Coding Approach by Allan Paivio (1986), Figure 4.1 (p.67).

Largely speaking, the fundamental of the cognitive theory of Dual Coding Theory and organizational of structures has described. How information is processed by the Dual Coding Theory is by activating two basic units and the relationships between them. Dual Coding Theory generally refers to the skills of reading and literacy, by looking at how information taken from sensory experience is mentally represented and encoded into two separate coding systems through different hierarchical characteristics qualitatively and can be operated independently, in parallel, or through interconnection.

Key points to this theory are the three ways of processing information in the opinion of Paivio:1. Representational level where verbal and nonverbal are directly effected. 2. Referential level, and 3. Associative Level. (Sadoski, 2013).

In the Dual Coding Theory, all cognitions, including perception, memory, meaning, and knowledge must be executed by representation operation within and between the two codes. This kind of infomation can get into a much deeper outlines for various activities related to literacy.

\section{METHOD}

This paper is using a literature study method, which examines and analyzes textbooks and journals about storytelling, Dual Coding Theory and mental imagery and as a preliminary study for further research.

\section{DISCUSSION}

\section{Storytelling through Dual Coding Theory}

In storytelling through Dual Coding Theory, the mental imagery becomes an important component catalyzing the storytelling to the best advantageous and assists in developing literacy skills, especially in the reading comprehension. Significant areas to develop through storytelling with Dual Coding Theory (Roney, 1989, Fredericks, 1997) are: 1.To strengthen the nerves (neural pathways), 2. Helping children to maintain their focus, 3 . To help building literacy skills and improve the skills of reading, writing and speaking, 4. To develop imagination through mental imagery, 5. To help children managing emotions and motivation, 6 . Enhance creativity, 7. Strengthening high-level of thinking skills (higher order thinking), 8. To develop skills in solving problem.

\section{CONCLUSIONS}

Storytelling is important in helping the development of children. Researchers who study brain and behavioral development identified that imagination is not only the core of creativity, but also an important substance to a higher order thinking.

Combining storytelling with mental imagery strategy in the Dual Coding Theory, will help opening up the capacity of imagination in a more profound way, not only for the sake of academic interest, but also for the behavior development as children with diverse experiences and rich on imagination are having more ability to be more creative, to speak better, able to manage emotions and have stronger motivation so they are able to look at the problem more clearly and solve problems better. 


\section{ACKNOWLEDGEMENTS}

I would like to express my sincere gratitude to Mr. Bachruddin Mustafa, M.A., Ph.D., my mursyid and advisor Dr. Zamzam Ahmad Jamaluddin T, M.Si., Miss. Sentari Tanuwijaya, Bubun Lysandri and Moch. Sya'ban Suwargana for the full support. Thank you for the patience, motivation, which without they precious support it would not be possible to conduct and finish this paper.

\section{REFERENCES}

Chesin, G. A. (2009). Storytelling and storyreading, (February 2015), 37-41. http://doi.org/10.1080/01619566609537343

Faizah, et.all. (1995). Panduan Umum Literasi untuk Mengembangkan Potensi Anak Seutuhnya, http://www.ayomembacaindonesia.org/?page_i $\mathrm{d}=2$

Fredericks, B. L. (1997). Developing Literacy Skills Through Storytelling.

Isbell, R., Sobol, J., Lindauer, L., \& Lowrance, A. (2004). The Effects of Storytelling and Story Reading on the Oral Language Complexity and Story Comprehension of Young Children, $32(3)$.

Paivio, A. (2006). Dual Coding Theory and Education, 1-20, University of Western Ontario.

Roney, R. C. (1989). Back to the basics with storytelling, 42(7), 520-523.

Sadoski, Mark, Paivio, A. (2013), Imagery and Text $:$ a dual coding theory of reding and writing, Second edition, UK:Routledge.

Sentari, (2002). Pengaruh Strategi Belajar Mental Imagery Terhadap Penguasaan Bacaan, Skripsi, Fakultas Psikologi, Universitas Indonesia, Depok.

Sukartiningsih, W. (2005). Peningkatan kemampuan membaca dan menulis permulaan melalui pembelajaran konstruktivisme. Jurnal Pendidikan Dasar, Vol.6 No.2, 61-118.

Surat Edaran Direktorat Jenderal Manajemen Pendidikan Dasar Dan Menengah Nomor 1839/C.C2/TU/2009 